\title{
Antropogén hatások becslése hazai talajokban felszínborítási adatok és WRB diagnosztika alapján
}

\author{
NovÁK Tibor József, InCZE József \\ Debreceni Egyetem, Természettudományi és Technológiai Kar, Tájvédelmi és \\ Környezetföldrajzi Tanszék \\ (Benyújtva: 2018. július 2.; Elfogadva: 2018. november 22.)

\section{Bevezetés \\ Az emberi tevékenység, mint talajképződést befolyásoló tényező}

Az ember által végzett tevékenységek jelenlétüktől kezdve hatást gyakorolnak a talajra. Hogy ez a hatás mikor válik olyan mértéküvé vagy jellegüvé, amely miatt azt a talajképződés többi tényezőitől megkülönböztetve egy hatodik talajképző tényezőként kell kezelnünk (DUDAL, 2005), arról megoszlanak az egyes szerzők nézetei. Az egyik álláspont szerint az ipari forradalom óta eltelt 2-300 év, vagy az ember és társadalom megváltozott viszonyára alapozva csak a második ipari forradalmat követő időszak tekinthető lényegesen új korszaknak a talajok fejlődésében (LEWIS \& MASLIN, 2015). Mások már az első kerámiák és fémtárgyak készítésétől, mintegy 5000 évvel ezelőttől számítják a korai Anthropocén és az antropogén talajok megjelenését (MONASTERSKY, 2015). Néhány szerző éppen az antropogén talajok, mint sztratigráfiailag megragadható entitások megjelenésében látják az új, emberi társadalom tevékenységei által lényegesen meghatározott földtörténeti kor, az Anthropocén bevezetésének jogosultságát (CERZINI \& SCALENGHE, 2011; RICHTER et al., 2015), és annak kezdetét mintegy 2000 évvel ezelőttre teszik.

A társadalom talajokra gyakorolt hatásait DUDAL et al. (2002), valamint DAZZI \& LO PAPA (2015) az alábbiakban foglalják össze:

1. a talajtípus (referencia csoport, osztály stb. egyéb taxonómiai egység) antropogén okok miatt történő megváltozása

2. diagnosztikai talajszintek antropogén megváltozása

3. új, antropogén talajképző kőzet

4. mélyreható antropogén talajbolygatás

5. felszínformák antropogén megváltozása

6. a feltalaj megváltozása antropogén folyamatok következtében

7. talaj tervszerủ létrehozása, helyreállítása

Az első két esetben a talaj megváltozását az osztályozáshoz alkalmazott rendszerben elfoglalt taxonómiai státus megváltozása jelzi. Ez azonban azonos mértékủ és jellegü talajváltozás esetén az azonos osztályozási rendszer alkalmazását is feltételezi, hiszen eltérő osztályozási rendszerben nem feltétlenül változik meg,

Postai cím: NOVÁK TIBOR JózSEF, Debreceni Egyetem, Természettudományi és Technológiai Kar, Tájvédelmi és Környezetföldrajzi Tanszék,

4002 Debrecen, Egyetem tér 1. pf. 400

E-mail: novak.tibor@science.unideb.hu 
vagy éppen sokkal kisebb változás hatására is megváltozik a taxonómiai besorolás helyzete azonos mértékủ és jellegủ antropogén hatások következtében. Ugyanakkor ennek megállapításához az osztályozási rendszernek nem kell feltétlenül tartalmaznia antropogén bélyegek leírására alkalmas diagnosztikai elemeket, viszont bizonyíthatóan antropogén eredetủnek kell lenni a besorolás megváltozásának.

A talajokban felismerhető antropogén hatások értékelése referencia hiányában gyakran nem, vagy csak feltételesen kvantifikálható. Rendkívül sokféle, eltérő jellegü hatásban nyilvánul meg, ezáltal a hatás erőssége nehezen vethetö össze objektív módon a különböző taxonokba tartozó talajokban. Az értékelést tovább nehezíti, hogy számos talajosztályozási rendszer nem, vagy nem elég hangsúlyosan foglalkozik a talajok antropogén jellemzőivel. Ez nem csak az osztályozásban, hanem néha már az adatgyüjtésben, illetve a mintavételi helyszínek kijelölésénél is érvényesül. A hagyományos talajtérképezés irányelvei között szerepel, hogy az emberi tevékenységgel érintett helyszíneket a szelvények, mintavételi helyek kijelölése során kerülni kell (BARANYAI, 1989; VÁRALLYAY \& FóRIZS, 1966). Éppen emiatt a talajokban megjelenő antropogén bélyegekről rendelkezésre álló információ is meglehetösen szükös, mind azok térbeli elterjedésére, mind pedig azok jellegére vonatkozóan. A jelenleg érvényben lévő hazai osztályozásban nem is szerepelnek az antropogén talajok (FöLDVÁRI, 1966; STEFANOVITS, 1992). Ha fótípusként említésre kerülnek is, sem további csoportosításukra, sem pedig a típusba sorolás egzakt kritériumaira vonatkozóan nincsenek pontos irányelvek. A megújuló hazai talajosztályozásban (FUCHS \& MichÉLI, 2015; MichÉLI et al., 2015; NOVÁK, 2013) erre vonatkozóan publikált új, WRB (World Reference Base for Soil Resources) elveket követő osztályozókulcs (FARSANG et al., 2015) egyelöre még nem került be a gyakorlatba. A talajok antropogén átalakítottságát kifejező egyik indexe a leromlottságot, azaz degradációt kifejező degradációs érték (MTA TAKI, 2011), amely elsősorban a termőképesség megváltozásának jellemzéséhez használatos. Mivel ennek használhatósága a mezőgazdasági területeken kívül korlátozott, tanulmányunkban kísérletet tettünk a felszínborítási adatok talajokra vonatkozó információinak eltérő módszerrel végzett értékelésére.

A talajtípus megváltozására a feltalaj lepusztulása következtében számos, korábbi eróziós kutatás szolgáltat példát (KERÉNYI, 1991; 1994; JAKAB, et al., 2015), amelynek következtében jól fejlett, vastag humuszos rétegủ talajokból (Luvisol, Phaeozem stb.) antropogén hatások következtében földes kopárok (Regosol) jöhetnek létre. Ugyancsak eróziós, de síkvidéki folyamatok eredményeként a talaj referencia csoport nem, csak a szelvényhez rendelhető minősítők ('nudinatric') változnak meg a réti szolonyec talajok padkás eróziója következtében (NovÁK \& TóTH, 2016).

Szintén a talajtípus megváltozásával járhat hazai réti talajok (Vertisol, Gleysol) vízrendezés hatására történő megváltozása, amikor másodlagosan kialakult réti szolonyec (Solonetz) talaj jöhet létre (SZABOLCS \& RÉDLY, 1989). A két talajtípus egyikének meghatározásához sem szükségesek, és a hazai osztályozásban nem is 
állnak rendelkezésre antropogén bélyegeket leíró diagnosztikai elemek (pl. diagnosztikai talajszintek, vagy tulajdonságok). Ám, ha a változás bizonyíthatóan emberi hatásra következett be, úgy ezek hiányában is megállapítható az antropogén átalakítottság és a talajtípus megváltozásának kapcsolata.

A felhagyott meddőhányók (CZIFRA \& NOVÁK, 2011) szemléletesen példázzák az antropogén talajképző ,kőzeten”, antropogén felszínforma-változást követően zajló humusz felhalmozódási folyamatokat. A létrejött talajokat Spolic Hyperskeletic Technosolként osztályozhatjuk. A Lyukó és Pereces-patak vízgyüjtőjén a bányászati tevékenységgel érintett, azaz a lefejtett, vagy meddővel borított felszíneken ezen talajok kiterjedése eléri a $20 \mathrm{~km}^{2}$-t (SÜTö et al., 2014). Bár ezekben a talajokban igen gyors $\left(0,1-4 \mathrm{t} \cdot \mathrm{ha}^{-1} \cdot \mathrm{e}^{-1}\right)$ a szerves vegyületek formájában történő szénmegkötés üteme (SHRESTHA \& LAL, 2006), de a finomfrakció hiánya, valamint a jelentős térfogatarányú durva törmelék miatt kapcsolata a talaj ásványi részeivel gyenge és labilis (CZIFRA \& NOVÁK, 2011; KUMAR et al., 2015).

Antropogén felszínformákon, mélyreható bolygatást követően létrejött talajokra szolgáltatnak példát a hegyaljai teraszozott lejtőkön kialakult talajszelvények (NoVÁK et al., 2014). A szőlőteraszok mellett kisebb területi kiterjedésben, más tájakon, gyümölcstermesztés céljából létesített teraszok (KISS et al., 2005) talajai is 'escalic' minősítőt kapnak. Az 'escalic' minősítésü talajok kiterjedése egyedül a tokaji Nagy-hegyen eléri az 1,2 $\mathrm{km}^{2}$-t (NOVÁK \& INCZE, 2014). A korábban jelentős antropogén beavatkozás eredményeként létrehozott teraszokra jelenleg Európa szerte a felhagyás, és a talajok spontán regenerációs folyamatai jellemzőek (ARNAEZ et al., 2010; GARCÍA-RUIZ, 2010; STANCHI et al., 2012; NovÁK et al., 2014).

A feltalaj megváltozására, antropogén hatások következtében felhalmozódott réteg kialakulására szolgáltatnak példát a hortobágyi jószágállások területén vizsgált réti szolonyec talajok (NovÁK et al., 2009).

Legszélsőségesebb példája a talajszelvények antropogén átalakítottságának a városi talajok esete, amelyekben az antropogén szubsztrátok, antropogén talajszintek (SÁNDOR et al., 2013; HORVÁTH et al., 2015), a mesterségesen létrehozott felszíneken kialakított áthalmozott talajrétegek együtt jelennek meg a természetes talajszintek maradványaival (BIDLÓ et al., 2014; VINCE et al. 2014).

\section{Anyag és módszer \\ Talajok antropogén bélyegeinek értékelése a WRB szerint}

A WRB osztályozás (IUSS Working Group WRB, 2015) szerint megállapított talajtani információk részletes lehetőséget nyújtanak a talajokat, és ezáltal a tájakat ért antropogén hatások mértékének kifejezésére (1. táblázat). Alkalmazásuk jelentős korlátja, hogy nagyon hiányos adatbázissal rendelkezünk WRB rendszerben leírt és osztályozott talajadatok tekintetében, amely nem elegendő ahhoz, hogy az ország teljes területét, tájanként differenciált módon erre vonatkozó adatokkal jellemezhessük. 


\section{1. táblázat}

Antropogén talajjellemzőket kifejező diagnosztikai elemek a WRB (IUSS Working Group WRB, 2015) talajosztályozási rendszerben

\begin{tabular}{|c|c|c|c|c|}
\hline $\begin{array}{l}\text { Referencia } \\
\text { csoportok } \\
\text { ANTHROSOL } \\
\text { TECHNOSOL }\end{array}$ & $\begin{array}{l}\text { Diagnosztikai } \\
\text { szintek } \\
\text { Anthraquic } \\
\text { Hortic } \\
\text { Hydragric } \\
\text { Irragric } \\
\text { Plaggic } \\
\text { Pretic } \\
\text { Terric }\end{array}$ & $\begin{array}{l}\text { Diagnosztikai } \\
\text { tulajdonság } \\
\text { Anthric } \\
\text { tulajdonság }\end{array}$ & $\begin{array}{l}\text { Diagnosztikai } \\
\text { talajanyagok } \\
\text { Mütermék } \\
\text { Technikai } \\
\text { szilárd anyag }\end{array}$ & $\begin{array}{l}\text { Minősítők } \\
\text { Anthraquic (aq) } \\
\text { Anthric (ak) } \\
\text { Archaic (ah) } \\
\text { Aric (ai) } \\
{\text { Densic* }{ }^{*}(\mathrm{dn})}_{\text {Drainic }^{*}(\mathrm{dr})} \\
\text { Ekranic (ek) }_{\text {Escalic (ec) }} \\
\text { Garbic (ga) } \\
\text { Hortic (ht) } \\
\text { Hydragric (hg) } \\
\text { Hyperartefactic(ja) } \\
\text { Irragric (ir) } \\
\text { Isolatic (il) } \\
\text { Linic (lc) } \\
\text { Murshic (mh) } \\
\text { Novic* (nv) } \\
\text { Plaggic (pa) } \\
\text { Relocatic (rc) } \\
\text { Spolic (sp) } \\
\text { Technic (te) } \\
\text { Technoleptic (tl) } \\
\text { Technolithic (tt) } \\
\text { Terric (tr) } \\
\text { Toxic (tx) } \\
\text { Transportic (tn) } \\
\text { Urbic (ub) }\end{array}$ \\
\hline
\end{tabular}

*antropogén és természetes eredetü is lehet

A WRB 35 diagnosztikai talajszint, 18 diagnosztikai tulajdonság és 17 diagnosztikai anyag definícióját alkalmazza. A referencia csoportba besorolt talajok pontosabb jellemzésére 201 minősítő szolgál, amelyek túlnyomó többsége föilletve kiegészítő minősítőként is állhat. A kifejezetten antropogén bélyegek jellemzésre ezek közül 7 diagnosztikai talajszint, 1 diagnosztikai tulajdonság, 2 diagnosztikai talajanyag és 27 minősítő használható (1. táblázat), amelyek tehát természetes folyamatok eredményeként elő sem fordulhatnak. Ebből a 27 minősítőből 3 (drainic, densic, novic) fejez ki olyan tulajdonságot, amely ugyan döntően antropogén tevékenység eredményeként jön létre, de természetes módon is elöfordulhat.

$\mathrm{Az}$ 1. tábázatban szereplő antropogén bélyegeket kifejező diagnosztikai elemek rövid, korántsem pontos, vagy teljes magyarázatát röviden az alábbiakban foglalhatjuk össze. 
Referencia csoportok:

1. ANTHROSOL: rendelkezik valamelyik antropogén diagnosztikai szinttel

2. TECHNOSOL: a felszíntől számított $100 \mathrm{~cm}$-en belül $\geq 20 \%$ tf müterméket, vagy mesterséges geomembránt tartalmaz, vagy technikai szilárd anyag kezdődik a felszíntől számított $5 \mathrm{~cm}$-en belül

Diagnosztikai szintek:

1. Anthraquic szint: árasztástól szétiszapolódott rétegből, és alatta eketalp rétegből álló szint;

2. Hortic szint: $\geq 20 \mathrm{~cm}$ vastag, nagy biológiai aktivitású, $\geq 100 \mathrm{mg} \cdot \mathrm{kg}^{-1} \mathrm{P}_{2} \mathrm{O}_{5}$ tartalmú kerti talajszint;

3. Hydragric szint: árasztás hatására, anthraquic szint alatt megjelenő, erösen vízhatású szint;

4. Irragric szint: jelentős üledék tartalmú öntözővíz hatására módosult felszíni talajszint;

5. Plaggic szint: szerves anyag ráhordással és bekeveréssel létrejött talajszint, óceáni klímán;

6. Pretic szint: hamu ráhordással és bekeveréssel létrejött talajszint, trópusi nedves klímán;

7. Terric szint: szerves anyagban gazdag adalék hozzáadásával és bekeverésével létrejött szint;

Diagnosztikai tulajdonságok:

1. Anthric tulajdonság: emberi bolygatás különféle nyomai mollic vagy umbric szintben

Diagnosztikai anyagok:

1. Mütermék: emberi tevékenység során előállított, módosított, vagy frissen felszínre hozott anyag

2. Technikai szilárd anyag: >95\%-ban összefüggő, mesterséges, ipari eredetü, vagy a természetestől eltérö anyag

Minősítők:

1. Anthraquic: anthraquic szintje van;

2. Anthric: anthric tulajdonságokkal rendelkezik;

3. Archaic: $\geq 20 \mathrm{~cm}$ vastag, $\geq 20 \%$ zömmel régészeti anyagból álló müterméket tartalmaz;

4. Aric: $\geq 20 \mathrm{~cm}$-ig szántott;

5. Densic: tömörödött;

6. Drainic: lecsapolt;

7. Ekranic: $\geq 5 \mathrm{~cm}$ vastag technikai szilárd anyaggal fedett;

8. Escalic: teraszozott felszínen található;

9. Garbic: $\geq 20 \mathrm{~cm}$ vastag $\geq 20 \%$ szerves hulladék eredetü müterméket tartalmaz;

10. Hortic: hortic szintje van;

11. Hydragric: hydragric szintje van; 
12. Hyperartefactic: $\geq 50 \%$ müterméket tartalmaz $100 \mathrm{~cm}$-en belül;

13. Irragric: irragric szintje van;

14. Isolatic: technikai szilárd anyag felett kialakult talaj, amelynek az eredeti talajjal nincs kapcsolata;

15. Linic: geomembránt, geotextilt tartalmazó talaj;

16. Murshic: tőzeges réteg, amely lecsapolás hatására repedezetté, szerkezetessé vált;

17. Novic: $>5$ és $<50 \mathrm{~cm}$ vastagságban az eredeti talaj felé ráhordott rétege van;

18. Plaggic: plaggic szintje van;

19. Relocatic: helyben áthalmozott anyagot tartalmaz;

20. Spolic: $\geq 20 \mathrm{~cm}$ vastag, $\geq 20 \%$ zömmel ipari, bányászati hulladékból álló müterméket tartalmaz;

21. Technic: a felső $100 \mathrm{~cm}$-en belül $\geq 10 \%$ müterméket tartalmaz;

22. Technoleptic: a felső $100 \mathrm{~cm}$-en belül technikai szilárd anyaga van;

23. Technolithic: a felső $10 \mathrm{~cm}$-en belül technikai szilárd anyaga van;

24. Terric: terric szintje van (tr);

25. Toxic: a felső $50 \mathrm{~cm}$-en belül emberi szervezetre mérgező szennyezést tartalmaz;

26. Transportic: müterméknek nem minösülö, $\geq 20 \mathrm{~cm}$ vastag, máshonnan odaszállított rétege van;

27. Urbic: $\geq 20 \mathrm{~cm}$ vastag, $\geq 20 \%$ zömmel építési törmelékből álló müterméket tartalmaz

A WRB 2014-es (IUSS Working Group WRB, 2014) kiadásának javított változata (IUSS Working Group WRB, 2015) 32 referencia csoportba sorolja a világ talajait, amelyből 2 referencia csoport (Anthrosol, Technosol) a kifejezetten antropogén tevékenység következtében létrejött talajokat foglal magában ( 1 . táblázat). Fontosabb azonban, hogy a WRB rendszer a többi referencia csoport esetében is lehetövé teszi az antropogén bélyegek kifejezését az osztályozásban, antropogén talajokra jellemző minősítők hozzáadásával. Ezek értékelése diagnosztikai talajszintek, diagnosztikai talajanyagok, illetve diagnosztikai tulajdonságok vizsgálatán alapul. A WRB az osztályozáshoz (referencia csoport és minősítők megállapításához) felhasznált diagnosztikai bélyegek (diagnosztikai talajszintek, diagnosztikai tulajdonságok és diagnosztikai talajanyagok) között is megkülönböztet olyanokat, amelyek kifejezetten emberi tevékenység következtében jönnek létre. Mivel a referencia csoportokba történő besorolás és a minősítők hozzárendelése elsősorban a diagnosztikai bélyegek megléte, hiánya, illetve szelvénybeli helyzete és vastagsága alapján történik, ezért az antropogén bélyegek kifejezésre juttatása már a tényleges osztályozási folyamat megkezdése elött, a szelvény leírása során is érvényesül. 
Antropogén hatások becslése ... adatok és WRB diagnosztika alapján

Talajok antropogén diagnosztikai bélyegeinek összekapcsolása a CLC adatokkal

Látható, hogy számos olyan antropogén bélyeg azonosítható önmagában a felszínborítás alapján, amely a WRB-ben diagnosztikai elem (FAO, 2006). Így például a beépített, városi területek esetében a felszínek lefedése, elegyengetése szilárd burkolata alapján a talajban a mütermékek, technikai szilárd anyagok jelenlétére következtethetünk. Közlekedési területeken, építési területeken a szilárd felszínburkolat nem csak a 'technikai szilárd anyag' jelenlétét, hanem az 'ekranic' minősítőt is jelzi. Szántóföldek talaja 'aric' minősítőt kap, a lerakóhelyek, meddőhányók, amelyek 'spolic' minősítóvel rendelkeznek, a kertségek, ahol gyakran 'hortic' talajszintek elöfordulásával, állandóan öntözött, vízzel elárasztott mezőgazdasági kultúrákban a 'hydragric, irragric' szintek meglétével számolhatunk. Vízrendezett, intenzív gyepek esetében a mesterséges lecsapolás következtében 'drainic' minősítőt kell alkalmaznunk stb.

A CORINE (CLC100) nomenklatúra 1.42 verzió standard 3. hierarchiaszintjének részletességével vizsgálva hazai területeken 32 különböző területhasználati kategória fordul elő (FÖMI, 2002, MARI \& MATTÁNYI, 2002; MARI, 2010). Ezekhez a 2. táblázatban szereplő módon számos talajtani diagnosztikai elem már a felszínborítási adatok alapján is hozzárendelhető, jósolható. A talajok természetességének rangsorolásához a WRB talajosztályozási rendszerben az antropogén hatás kifejezésére alkalmas diagnosztikai elemeit hozzárendeltük a CORINE (CLC100) felszínborítási osztályokhoz (FÖMI, 2002). Olyan csoportokba rendeztük, amelyekben a talajokat ért antropogén hatások mértéke hasonló (2. táblázat), és ezeket a WRB diagnosztika által használható hasonló referencia csoportok, diagnosztikai talajszintek, talajanyagok, és tulajdonságok is megjelenítik. A CORINE adatbázis vektoros formátumban állt rendelkezésünkre. Az egyes felszínborítási egységek összevonására, valamint az új csoportok kialakítására QGIS 2.18-et, míg az elemzésekhez és a térképi adatbázis elkészítéséhez Arc GIS 10 szoftvert használtunk.

A felszínborítási osztályok alapján képzett csoportok az alábbiak (2. táblázat): Azok a területek, ahol:

○ nincs talajtakaró (IUSS WRB 2007, definíció szerint)

○ döntően antropogén talajok találhatók (Technosol, Anthrosol)

- antropogén hatások nyomait viselő talajok találhatók (természetes referencia csoportok, antropogén minősítőkkel)

○ természetes, vagy természetközeli állapotú talajok találhatók (nincs antropogén diagnosztikai bélyeg)

Az első kategóriába csak olyan felszínborítási kategóriák kerültek, amelyeket a WRB nem osztályoz talajként, azaz a felszíntől számított 2 méteren belül minden olyan anyag, amely nem élőlény, és amelyet nem borít összefüggő jég, vagy 2 méternél mélyebb víz (IUSS Working Group WRB, 2015). Így - a talajok hazai értelmezésétől eltérően - az összefüggő természetes kőzetfelszínek, illetve a városi, ipari burkolt felszínek is értékelésre kerültek. 


\section{2. táblázat}

A CORINE (CLC100) felszínborítási kategóriák csoportosítása a talajokra jellemző antropogén átalakítottság mértéke alapján és az egyes kategóriákra jellemző WRB diagnosztikai bélyegek (zárójelben, dőlt szedéssel az előforduló, de nem feltétlenül megjelenő bélyegek)

\begin{tabular}{|c|c|c|c|}
\hline \multirow{2}{*}{$\begin{array}{l}\text { Felszínborítási kategóriák } \\
\text { (CLC100) }\end{array}$} & \multicolumn{2}{|c|}{$\begin{array}{c}\text { A felszínborítási csoportra jellemző } \\
\text { antropogén diagnosztikai bélyegek a } \\
\text { WRB alapján }\end{array}$} & \multirow{2}{*}{$\begin{array}{c}\text { Talajok antropogén } \\
\text { átalakítottságának } \\
\text { mértéke }\end{array}$} \\
\hline & Minősítő & $\begin{array}{l}\text { Referencia } \\
\text { csoport }\end{array}$ & \\
\hline 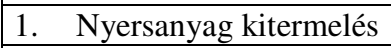 & - & \multirow{3}{*}{-} & \multirow{3}{*}{ - Nincs talajtakaró } \\
\hline 2. $\quad$ Folyóvizek, vízi utak & - & & \\
\hline 3. Állóvizek & - & & \\
\hline $\begin{array}{|ll|}4 . & \begin{array}{l}\text { Összefüggő település } \\
\text { szerkezet }\end{array} \\
\end{array}$ & ek, te, ub $(a h, d n, j a, i l)$ & \multirow{10}{*}{$\begin{array}{c}\text { AT } \\
\text { vagy } \\
\text { TC }\end{array}$} & \multirow{10}{*}{ Antropogén talajok } \\
\hline $\begin{array}{|ll|}5 . & \begin{array}{l}\text { Nem összefüggö } \\
\text { település szerk. }\end{array} \\
\end{array}$ & ek, ht $(a k, d n)$ & & \\
\hline \begin{tabular}{|ll}
6. & Ipari vagy \\
& kereskedelmi ter.
\end{tabular} & $\begin{array}{l}\text { ek, te }(d n, i l, j a, t x, t n, \\
u b)\end{array}$ & & \\
\hline 7. Út- és vasúthálózatok & ek, te $(i l, j a, l c, r c)$ & & \\
\hline 8. $\quad$ Kikötők & ek, ja, te $(i l, l, r c)$ & & \\
\hline 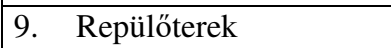 & ek, te $(j a, i l, r c)$ & & \\
\hline $\begin{array}{|ll|}\text { 10. } & \begin{array}{l}\text { Lerakóhelyek } \\
\text { (meddőhányók) }\end{array} \\
\end{array}$ & $\operatorname{sp}(g a, j a, l c, t x)$ & & \\
\hline 11. Építési munkahelyek & $\operatorname{dn}(e k, j a, r c, t n, u b)$ & & \\
\hline 12. Városi zöldterületek & $\mathrm{dn}, \operatorname{tn}(r c, t n, u b)$ & & \\
\hline $\begin{array}{l}\text { 13. Sport-, szabadidő- és } \\
\text { üdülő ter. }\end{array}$ & $\mathrm{dn}, \operatorname{tn}(e k, j a, r c, u b)$ & & \\
\hline \begin{tabular}{|l} 
14. \\
$\begin{array}{l}\text { Nem-öntözött } \\
\text { szántóföldek }\end{array}$
\end{tabular} & ai $(a k)$ & \multirow{8}{*}{ (A) } & \multirow{8}{*}{$\begin{array}{c}\text { Talajok jelentős } \\
\text { antropogén hatással }\end{array}$} \\
\hline \begin{tabular}{|l|} 
15. Állandóan öntözött \\
szántóföldek
\end{tabular} & ai $(a q, h g, i r)$ & & \\
\hline 16. Rizsföldek & ai $(a q, h g$, ir $)$ & & \\
\hline 17. Szőlök & ai $(a k, e c, r c)$ & & \\
\hline \begin{tabular}{|l}
$\begin{array}{l}\text { 18. Gyümölcsösök, } \\
\text { bogyósok }\end{array}$ \\
\end{tabular} & ai $(a k, e c)$ & & \\
\hline $\begin{array}{l}19 . \begin{array}{l}\text { Intenzív legelök és } \\
\text { erősen degradált } \\
\text { gyepterületek }\end{array} \\
\end{array}$ & $\mathrm{dn}$ & & \\
\hline \begin{tabular}{|l} 
20. \\
Komplex müvelési \\
szerkezet
\end{tabular} & ai $(a k, h t)$ & & \\
\hline \begin{tabular}{|l} 
21. \\
Elsődlegesen \\
mezőgazdasági ter.
\end{tabular} & ai $(a k, h t)$ & & \\
\hline
\end{tabular}




\begin{tabular}{|c|c|c|c|}
\hline \multicolumn{4}{|c|}{ 2. táblázat folytatása } \\
\hline 22. Lomblevelü erdők & - & \multirow{11}{*}{-} & \multirow{11}{*}{$\begin{array}{l}\text { Természetes, vagy } \\
\text { természetközeli } \\
\text { állapotú talajok }\end{array}$} \\
\hline 23. Tülevelü erdők & - & & \\
\hline 24. Vegyes erdők & - & & \\
\hline $\begin{array}{l}\text { 25. Természetközeli } \\
\text { gyepek }\end{array}$ & $(d r)$ & & \\
\hline $\begin{array}{l}\text { 26. Átmeneti erdős-cserjés } \\
\text { terület }\end{array}$ & - & & \\
\hline $\begin{array}{l}\text { 27. Homokpadok, } \\
\text { zátonyok, dủnék }\end{array}$ & $(n v)$ & & \\
\hline 28. Csupasz sziklák & - & & \\
\hline 29. Ritkás növényzet & - & & \\
\hline 30. Leégett területek & - & & \\
\hline 31. Szárazföldi mocsarak & $(d r)$ & & \\
\hline 32. Tőzeglápok & $(d r, m h)$ & & \\
\hline
\end{tabular}

A felszínborítási osztályok tehát olyan csoportokba rendezhetők, amelyek kifejezik az antropogén hatások erősségének különbségeit. Ezáltal a felszínborítási adatok alapján tehetők olyan predikciók, amelyek a talajok antropogén átalakítottságának mértékét fejezik ki.

A fenti négy kategória alkalmazásával a felszínborítási adatok újraosztályozásával elkészítettük az ország területére a talajok természetességét ábrázoló térképet (1. ábra). Továbbá meghatároztuk a fent definiált csoportok térbeli kiterjedését a genetikai talajtípustól függően (a genetikai talajtípusok kiterjedésével (MTA TAKI, 2009) történő összevetés alapján, 2. ábra). A kategóriák térbeli megoszlását középtájakra bontva is megvizsgáltuk (középtájhatárokkal történő összevetés alapján, 3. ábra), amelynek segítségével még pontosabb képet adhatunk hazánk talajtakaróját ért antropogén hatások térbeli eloszlásáról.

\section{Eredmények}

\section{Talajok antropogén átalakítottságának mértéke Magyarországon (2012)}

A fentiek szerint elkészítettük az ország területének antropogén talajbolygatottság természetesség térképét. A 2012-es CLC100 felszínborítási adatok alapján Magyarország területének 2,106\%-át $\left(1918 \mathrm{~km}^{2}\right)$ olyan felszínborítási kategóriák jellemzik, ahol egyáltalán nincs talaj, 6,0\%-ot $\left(5581 \mathrm{~km}^{2}\right)$ tesznek ki a döntően antropogén talajokkal (Technosol, Anthrosol) jellemezhető felszínborításba tartozó területek. Azon területek aránya, ahol a természetes talajokat a WRB osztályozás szintjén is kifejezhető antropogén hatások érték $65,91 \%\left(61312 \mathrm{~km}^{2}\right)$. Itt a változás mértéke nem éri el azt a diagnosztikai szintet, hogy WRB alapján valamelyik antropogén referencia csoportba kerüljenek. Legfeljebb a mezőgazdasági területeken jellemző Anthrosolok kritériumait elégítik ki. A felszínborítási kategóriák alapján várhatóan döntően természetes, vagy természetközeli talajokkal rendelkező területek aránya 26,03\% $\left(24217 \mathrm{~km}^{2}\right)$. A fenti 
kategóriák területi eloszlásának különbségeit a 2012-es adatok alapján a 1.ábra mutatja be.

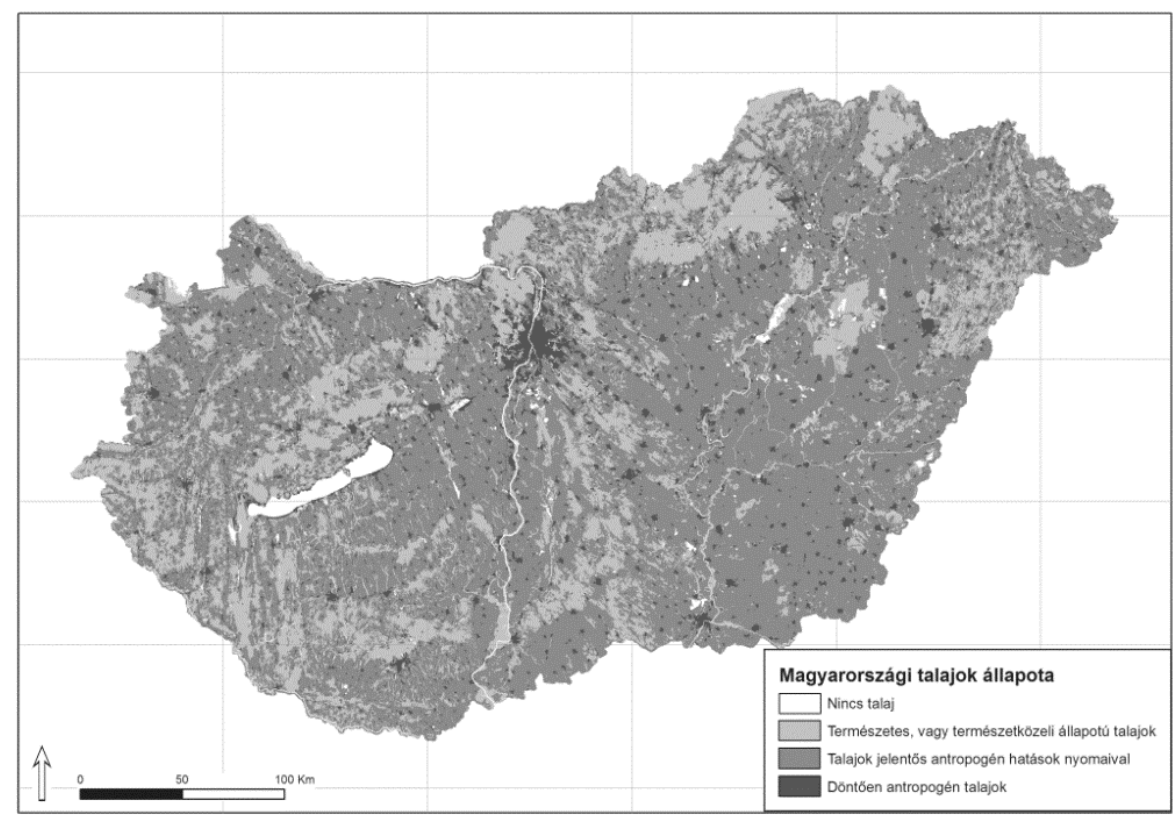

1. Ábra

Talajok antropogén átalakítottságának CLC100 (2012) felszínborítási kategóriák alapján várható mértéke Magyarországon

Főtípusok szerinti megoszlás alapján arányait tekintve (2. ábra) legnagyobb részesedéssel az öntés talajokon fordulnak elő antropogén talajok $(8,8 \%)$, amelyet a csernozjomok $(6,3 \%)$ és a barna erdötalajok $(6,1 \%)$ követnek. Eredményeink alapján ez azt jelzi, hogy itt valójában már egyáltalán nem ezeket a fötípusokat, hanem a megadott területi részesedésben antropogén talajokat találunk. Antropogén talajok legkisebb arányban a mocsári erdő $(2,0 \%)$ talajokból és a szikes talajokból $(2,5 \%)$ foglalnak el területet. A referencia csoport szerint nem antropogén, de jelentős antropogén bélyegeket felmutató talajok legnagyobb arányban csernozjomok $(88,3 \%)$ és réti talajok $(76,3 \%)$ között találhatók. Természetes állapotú talajok legnagyobb arányban a kőzethatású $(75,4 \%)$ és a váztalajokból $(42,8 \%)$, legkisebb arányban a csernozjomokból $(4,7 \%)$ maradtak meg. 


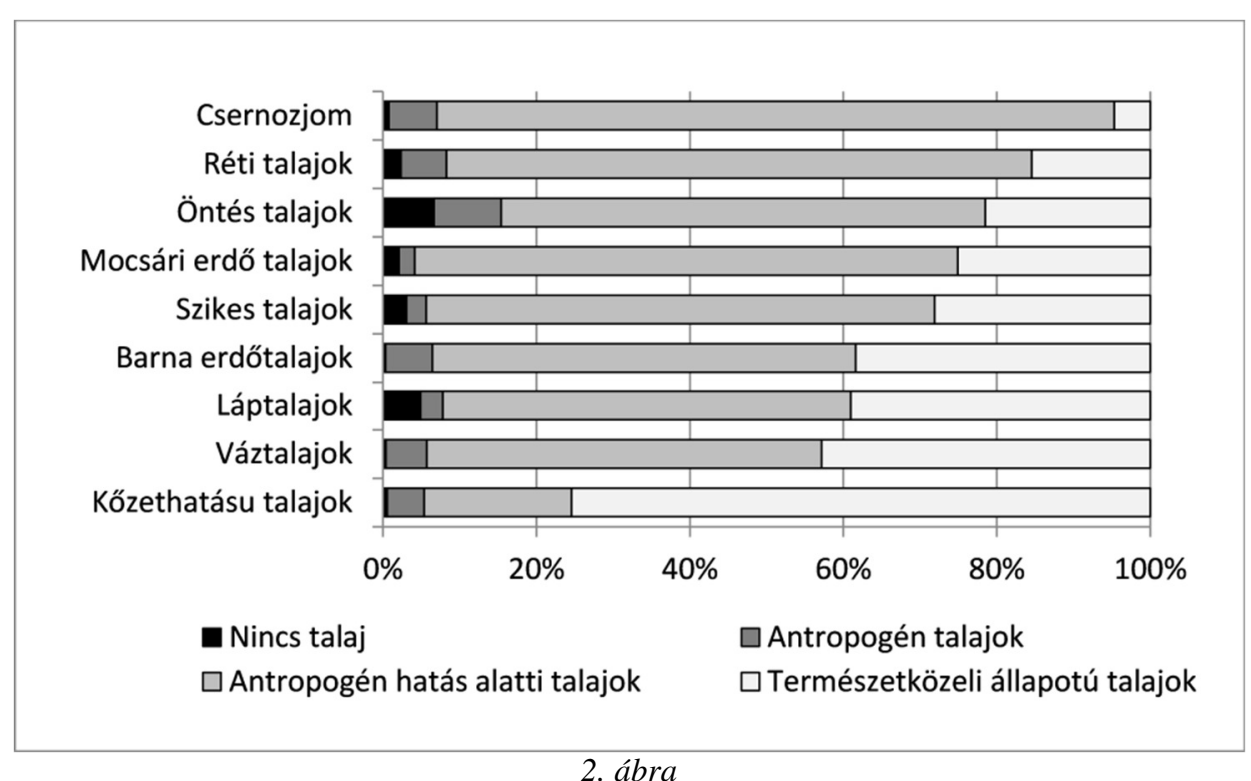

Talajok antropogén átalakítottságának megoszlása genetikai fötípusok területére vetítve Magyarországon

A négy kategória elterjedésének földrajzi különbségeit középtájakra bontva is megvizsgáltuk (3. ábra). Az antropogén talajok legnagyobb arányban a Dunazughegyvidéken (16,9\%), a Duna menti síkságon (13,1\%) és a Komárom-Esztergomisíkságon (10,1\%), míg a legkisebb arányban az Aggtelek-Rudabányai-hegyvidéken $(3,0 \%)$, a Dráva menti síkságon $(3,0 \%)$ és a Börzsönyben $(2,2 \%)$ fordulnak elö. Az antropogén hatásokkal erőteljesen érintett, de nem antropogén referencia csoportba tartozó talajok aránya a Hajdúságban $(88,1 \%)$, a Körös-Maros-közén $(89,3 \%)$, és a Berettyó-Körös-vidéken (81,9\%) a legnagyobb, míg a Börzsönyben $(19,3 \%)$, a Visegrádi-hegységben (23,3\%) illetve a Tokaj-Zempléni-hegyvidéken $(35,6 \%)$ a legkisebb. Az utóbbi három középtájban találjuk ugyanakkor legnagyobb arányban a természetes, vagy természetközeli állapotú talajokat is (sorrendben: 78,4\%; $61,5 \% ; 60,7 \%)$. Természetes állapotú talajok legkisebb arányban a Hajdúságon (4,0\%), a Körös-Maros-közén (5,5\%) és a Komárom-Esztergomi-síkságon $(10,1 \%)$ fordulnak elö. 


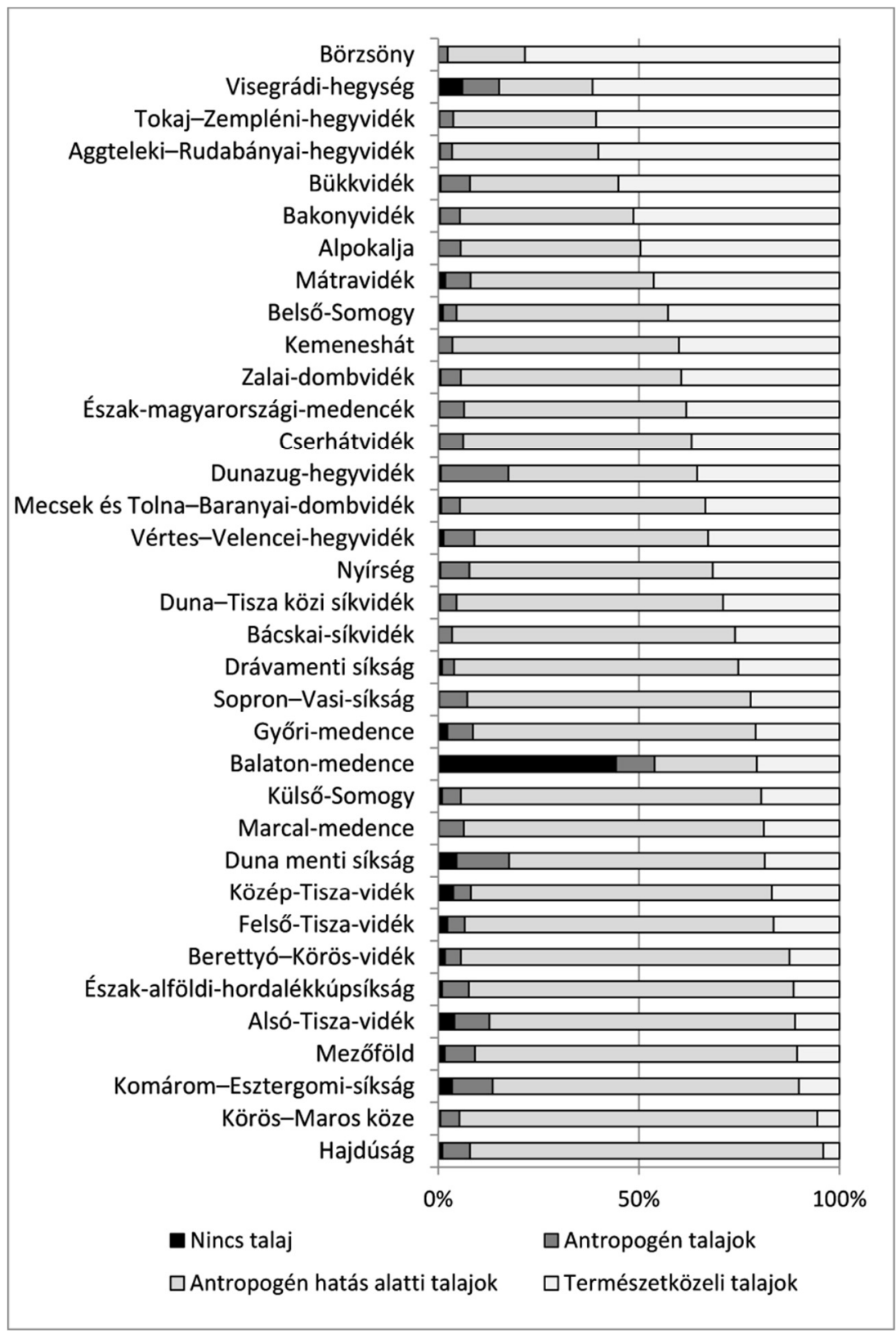

\section{3. ábra}

Talajok antropogén átalakítottságának középtáji különbségei Magyarországon 


\section{Diszkusszió}

A talajok alkalmazása az antropogén tájátalakítottság mértékének kifejezésére azért tünik alkalmasnak, mert a növényzet változásaihoz hasonlóan a többi tájalkotó tényező hatásai (alapkőzet, morfológia, klíma, idő) összegződnek benne. A növényzettől eltéröen az antropogén hatásokat követő talaj-regenerációs folyamatokhoz szükséges idő lényegesen hosszabb. A vegetáció viszonylag gyors regenerációs képessége miatt igen jelentős, akár a teljes felszínt átalakító emberi hatások is felismerhetetlenné, értékelhetetlenné válnak néhány száz év elteltével. Az adott táj antropogén átalakítottságának mértékét, a vegetáció állapota alapján megállapított természeti tőke index, vagy hemeróbia ilyenkor erősen alábecsülheti. Ezzel szemben a gyakran, vagy frissen, de csak felszínesen bolygatott területeken az antropogén hatás mértékét a vegetáció alapján megállapított indexek túlbecsülik. További nehézséget okoz, hogy a természetes vegetációval nem rendelkező felszínek között az antropogén hatások tekintetében a természeti tőke index egyáltalán nem, a hemeróbia pedig csak a felszínborítási kategóriák szerint tesz különbséget. Egy szántóföldi, és egy ipari terület antropogén hatások tekintetében azonban nem tekinthető egyformának, ahogyan egy települési és egy ipari terület sem.

Természetes állapotú talajok termőrétegének növekedési üteme 0,0001-0,6 $\mathrm{mm}$ év ${ }^{-1}, 0,027 \mathrm{~mm} \mathrm{év}^{-1}$ középértékkel (STOCKMANN et al., 2014). A talajokba került anyagok tartózkodási ideje stabil állapotban terresztris kozmogén izotópok mennyiségének meghatározása alapján 47000 év (STOCKMANN et al., 2014). Ehhez képest a talaj felső rétegének antropogén átalakítása nagyságrendekkel gyorsabb folyamat, mind a talajréteg vastagságának változását, mind a talaj elemeinek tartózkodási idejét tekintve. Az antropogén átalakítás rendkívül gyors üteme mellett még a degradált talajok regenerációja esetén is a primer talajképződéshez képest sokkal gyorsabb folyamattal számolhatunk. A humuszos réteg vastagságának növekedését, a szerves-szén készlet változásait vizsgáló tanulmányok megállapításai szerint a folyamat első fázisában néhány évtized alatt, viszonylag gyors szervesanyag-készlet növekedés tapasztalható (POST \& KwON; 2000; GuO \& GIFFORD, 2002; MCLAUCHLAN et al., 2006; LAGANIÈRE et al. 2010;), de a természetes talajokra jellemző szintet a talajtípus függvényében csak 150-200 év alatt érik el (KALININA et al., 2011). Az antropogén hatásokra jellemző bélyegek azonban (bolygatott szintek, szerves anyag felhalmozódás, mütermékek, stb.) megfelelő módszerekkel még több ezer év távlatából is kimutathatók. 
A talaj, mint tájalkotó tényező használata tehát több okból is rendkívül alkalmasnak tủnik a tájak antropogén átalakítottságának jellemzésére:

1. a talajban az öt (emberi. hatásokkal együtt hat) talajképző tényező (egyúttal tájalkotó tényező), hatása összegződik, ezáltal érzékenyen reflektál azok térben heterogén mintázatára;

2. az élövilágnál konzervatívabb tájalkotó tényezőként a benne megjelenő hatások hosszabb időn keresztül megőrzik a korábbi hatások nyomait, ezért esetenként több ezer évvel ezelötti hatásokat is archiválnak.

3. korábbi használat felhagyását követően rövid idő alatt is számottevő regenerálódási folyamat indul el, amely alapján az antropogén átalakítás mértéke csökkenhet is

Természetesen pontos képet akkor kaphatnánk ezúton a tájak antropogén átalakítottságáról, ha nagy sűrüségben, WRB diagnosztika szerint felvett talajadatok állnának rendelkezésre. Ugyanakkor a fenti, (és a későbbiekben részletesen bemutatott) becslés alapján az egész ország területén tájanként differenciált módon mutatható be az antropogén hatás erőssége, illetve annak időbeli változásai.

\section{Összefoglalás}

A WRB diagnosztikai elemeit és a felszínborítási adatokat kombinálva a talajokat ért antropogén hatás mértéke szerint négy csoportot alkottunk: 1. nincs talaj, 2. antropogén eredetü talaj, 3. természetes talaj, de lényeges antropogén bélyegekkel, illetve 4 . természetes talaj. A négy csoport valamelyikéhez egyértelmủen hozzárendelhető a felszínborítási osztályok mindegyike. Az általunk kidolgozott módszer segítségével értékeltük Magyarország talajtakarójának természetességét. Az ország területének 2\%-án nem számolhatunk a FAO által definiált értelemben talaj létével, 6\%-án antropogén talajok várhatók (Anthrosol, vagy Technosol), 66\%-án a természetes talajok antropogén átalakítottsága eléri a WRB diagnosztikai határértékeit, és mindössze $26 \%$ azon talajok aránya, amelyekben antropogén hatások a diagnosztikában nem jelennek meg, azaz természetes vagy természetközeli állapotúként értékelhetők. Talajtípusok tekintetében legnagyobb mértékủ emberi hatással a csernozjomok, réti és öntés talajok esetében számolhatunk, míg természetközeli állapotú talajok legnagyobb kiterjedésben a kőzethatású és váztalajokon maradtak fenn. A területi különbségek is jelentősek: míg legnagyobb arányban a Hajdúságon és a Körös-Maros közén találunk antropogén hatásokkal érintett talajokat, addig a természetközeli állapotú talajok aránya az Északi-középhegység egyes hegyvidéki területein a legnagyobb.

Módszerünk csak becslésre alkalmas, mégis jó áttekintést ad a hazai talajok antropogén átalakítottságának mértékéről, az emberi tevékenység, mint hatodik talajképző tényező jelentőségéről, intenzitásának térbeli eloszlásáról, amely a hazai talajtani adottságoknak egy eddig kevéssé vizsgált aspektusa. 
Kulcsszavak: antropogén hatások, talaj természetessége, felszínborítás, WRB diagnosztika

A tanulmány a Bolyai János Kutatási Ösztöndíj támogatásával készült.

\section{Irodalom}

Arnaez, J., Lasanta, T., ERREA, M.P., OrtigOSA, L. 2010. Land abandonment, landscape evolution, and soil erosion in a Spanish Mediterranean mountain region: The case of Camero Viejo, Land Degradation \& Development. 22. (6) 537-550.

BARANYAI F. (szerk.) 1989. Útmutató a nagyméretarányú országos talajtérképezés végrehajtásához. Melioráció-öntözés és talajvédelem. Agroinform. Budapest pp. 51-55.

BidLó A, GÁlos B, HoRvÁth A. 2014. The impact of climate change on carbon storage of urban soils Geophysical Research Abstracts. 16. Paper EGU201413493.

Cerzini, G., SCALEnghe, R. 2011. Anthropogenic soils are the golden spikes for the Anthropocene. The Holocene. 21. (8) 1269-1274.

CLC100 Copernicus Land Monitoring Services, Pan-European CORINE Land Cover Database (http://land.copernicus.eu/pan-european/corine-land-cover)

CZIFRA L., NOVÁK T. J. 2011. Spontán rekultiválódó meddőhányók talajának és növényzetének fejlődési sajátosságai a Bán-patak völgyében. In: WANEK F. (ed.) 2011. XIII. Bányászati, Kohászati és Földtani Konferencia absztraktkötete, Erdélyi Magyar Múszaki Tudományos Társaság, Kolozsvár, pp. 292-293.

DAZZI, C., LO PAPA, G. 2015. Anthropogenic soils: general aspects and features. Ecocycles. 1. (1) 3-8.

DUDAL, R 2005. The sixth factor of soil formation. Eurasian Soil Science. 38. 60.

Dudal, R., NAchtergaele, F., Purnell, M.F. (2002) The human factor of soil formation. In:17th World Congress of Soil Science Paper No. 93. Bangkok, Thailand (CD-ROM) (IUSS).

FARSANG, A., SZOLNOKI, Zs., BARTA, K., PUSKÁS, I. 2015. Javaslat az antropogén talajok osztályozására a hazai, megújuló osztályozási rendszer keretei között. Agrokémia és Talajtan. 64. (1) 299-316.

Food \& AgRiculture Org. OF THE United NATIONS 2006. Guidelines for soil description. Fourth edition, Rome, FAO, pp. 97.

FÖLDVÁRI GY. 1966. Magyarország genetikus talajtípusainak, altípusainak és változatainak szisztematikus jegyzéke In: SzABOLCS I. (szerk.)(1966). A genetikus üzemi talajtérképezés módszerkönyve, Országos Mezőgazdasági Minőségvizsgáló Intézet, Budapest, pp. 165-254.

FÖMI 2002. Az 1:50.000 léptékủ országos CORINE Felszínborítási (LandCover) Projekt nómenklatúrája. FÖMI, Budapest,(CLC50 1.42 verzió, 2002. január 10.) pp. 20. 
FuCHS, M., MiCHÉLI, E. 2015. Javaslat a hazai genetikai talajszintek leírásának a FAO irányelveknek megfelelő módosítására. Agrokémia és Talajtan. 64. (1) 273-285.

GARcíA-RuIZ, J.M. 2010. The effects of land uses on soil erosion in Spain: A review. Catena 81. (1) 1-11.

GUO, L.B., GIFFORD, R.M. 2002. Soil carbon stocks and land use change: a meta analysis. Global Change Biology 8. 345-360.

HoRvÁTH A, SzÜCS P, BIDLÓ A. 2015._Soil condition and pollution in urban soils: evaluation of the soil quality in a Hungarian town. Journal of soils and sediments. 15. (8) 1825-1835.

IUSS Working Group WRB 2007. World Reference Base for Soil Resources 2006, World Soil Resources Reports, No. 103. FAO, Rome, pp. 93.

IUSS Working Group WRB, 2014. World Reference Base for Soil Resources 2014, World Soil Resources Reports, No. 106. FAO, Rome, pp. 181.

IUSS Working Group WRB, 2015. World Reference Base for Soil Resources 2015, World Soil Resources Reports, No. 106. FAO, Rome, pp. 192.

JAKAB G, SZABó J, SzAlai Z. 2015. A review on sheet erosion measurements in Hungary. Tájökológiai Lapok. 13. (1) 89-103.

Kalinina, O., Krause, S.-E., GoryachKin, S.V., Karavaeva, N. A., LyURI, D.I., GIANI, L., 2011. Self-restoration of post-agrogenic chernozems of Russia: Soil development, carbon stocks, and dynamics of carbon pools. Geoderma. 162. 196-206.

KERÉNYI A. 1991. Talajerózió, térképezés, laboratóriumi és szabadföldi kísérletek, Akadémiai Kiadó, Budapest, 219 p.

KERÉNYI, A. 1994. Loess erosion on the Tokaj Big-Hill. Quaternary International. 24. 47-52.

Kiss, A., BARTA, K., SÜMEghy, Z., CZINEge, A., 2005. Historical land use and anthropogenic features, a case study from Nagymaros. Acta Climatol. Chorologica Univ. Szeged. 38-39. 111-124.

Kumar, S., MaITI, S.K., ChaudHuRI, S. 2015. Soil development in 2-21 years old coalmine reclaimed spoil with trees: A case study from Sonepur-Bazari opencast project, Raniganj Coalfield, India. Ecological engineering. 84. 311324.

LAGANIÈRE, J., ANGERS, D. A., PARÉ, D. 2010. Carbon accumulation in agricultural soils after afforestation: a meta-analysis. Global Change Biology. 16. 439-453.

LEWIS, S.L., \& MASLIN, M.A. 2015. Defining the Anthropocene. Nature. 519. 171180.

MARI L. 2010. Tájváltozás elemzés a CORINE adatbázisok alapján. In: SzILASSI P.\& Henits L. (szerk.) (2010). Tájváltozás értékelési módszerei a 21. században. Tudományos konferencia es mühelymunka tanulmányai, 2010, Szeged, pp. 226-234.

MARI L., MATTÁNYI ZS. 2002. Egységes európai felszínborítasi adatbázis a CORINE Land Cover program - Földrajzi Közlemények. 126/50. (1-4) 31-38. 
Mclauchlan, K.K., HobBIE, S.E., Post, W. 2006. Conversion from agriculture to grassland builds soil organic matter on decadal time scales. Ecological Applications. 16. (1) 143-153.

Michéli, E., Fuchs, M., LÁng, V., Szegi, T., Dobos, E., SzabónÉ Kele,G. 2015. Javaslat talajosztályozási rendszerünk megújítására: alapelvek, módszerek, alapegységek. Agrokémia és Talajtan. 64. (1) 285-297.

MONASTERSKY, R. 2015. Anthropocene - the human age. Nature. 519. 144-147.

MTA TAKI 2009. Magyarország genetikai talajtérképe, főtípusok. 1:100 000, Az 1:100 000 AGROTOPO és OTAB adatbázisok alapján, MTA TAKI GIS Laboratórium

MTA TAKI 2011. Az Országos Környezeti Információs Rendszer (OKIR) talajdegradációs alrendszerének (TDR) kialakítása. Tájökológiai Lapok. 9. (1) 203-205.

NOVÁK, T., BECKER, K., GIANI, L. 2009. Modification of solonetz soil profile characteristics caused by organic matter influx on the livestock resting sites of Hortobágy, Hungary, In: Tóth, T. (ed.) (2009). IUSS Salinization Conference Presentations, RISSAC-MTA TAKI, Budapest. pp. 33.

NovÁK, T.J. 2013 Talajtani Praktikum - Talajok terepi vizsgálata, leírása és osztályozása. Meridián Alapítvány, Debrecen. pp. 188.

NovÁK, T.J., INCZE J. 2014. A tokaji Nagy-hegy felhagyott szőlőteraszainak támfalai - Retaining walls of abandoned vineyard terraces on Tokaj Nagy Hill. 4D Tájépítészeti és kertmüvészeti folyóirat - Journal of Landscape Architecture and Garden Art. 35. 20-35.

NovÁK, T.J., InCZE, J., SpOHN, M., GlinA, B., Giani, L. 2014. Soil and vegetation transformation in abandoned vineyards of the Tokaj Nagy-Hill. Catena. 123. 88-89.

NovÁK, T.J., Tóth, C. A. 2016. Development of erosional microforms and soils on semi-natural and anthropogenic influenced solonetzic grasslands. Geomorphology. 254. 121-129.

Post, W. M., Kwon, K. C. 2000. Soil carbon sequestration and land-use change: processes and potential. Global Change Biology. 6. (3) 317-328.

Richter, D.,DEB., BACON, A.R., Brecheisen,Z., Mobley, M.L. 2015. Soil in the Anthropocene. IOP Conf. Ser.: Earth Environ. Sci. 25. 1-11.

SÁndor, G., SzABÓ, GY., Charzyński, P., SZYNKowsKa, E., NovÁK, T.J., ŚWITONIAK, M. 2013. Technogenic soils in Debrecen. In: CHARZYŃSKI, P., MarkiewiCZ, M., ŚwitoniaK, M. (eds.) (2013). Technogenic Soils Atlas, Polish Society of Soil Science. Toruń. 35-74.

SHRESTHA, R.K., LAL, R. 2006. Ecosystem carbon budgeting and soil carbon sequestration in reclaimed mine soil. Environment International. 32. 781-796.

Stanchi, S., FreppaZ, M., Agnelli, A., Reinsch, T., Zanini, E. 2012. Properties, best management practices and conservation of terraced soils in Southern Europe (from Mediterranean areas to the Alps): A review. Quaternary International. 265. 90-100.

StefanOVITS, P. 1992. Talajtan (3. kiadás) Mezőgazda Kiadó, Budapest. pp. 379. 
Stockmann, U., Minasny, B., McBRatney,A.B. 2014. How fast does soil grow? Geoderma. 216. 48-61.

SÜTŐ, L., DobÁNY, Z., NovÁK T. J., INCZE J., RóZSA P. 2014. Antropogén tájak összehasonlító elemzése - esettanulmányok Borsod-Abaúj-Zemplén megyéből. Észak-magyarországi Stratégiai Füzetek. 11. (2) 45-52.

SzabOlCS, I., RÉDlY, M. 1989. State and Possibilities of Soil Salinization in Europe. Agrokémia és Talajtan. 38. (3-4) 537-558.

VÁRALLYAY GY. ,FóRIZS J.-NÉ 1966. A helyszíni talajfelvételezés In: SZABOLCS I. (szerk.) (1966). A genetikus üzemi talajtérképezés módszerkönyve, Országos Mezőgazdasági Minőségvizsgáló Intézet, Budapest. pp. 19-160.

Vince, T., Szabó, G., Csoma, Z., SÁndor, G., SzabÓ, S. 2014. The spatial distribution pattern of heavy metal concentrations in urban soils - a study of anthropogenic effects in Berehove, Ukraine. Central European Journal of Geosciences. 6. (3) 330-343.

\section{Estimation of the extent of anthropogenic transformation of Hungarian soils based on land cover and WRB diagnostics}

\section{T. J. NOVÁK, J. INCZE}

Department of Landscape Protection and Environmental Geography, Faculty of Sciences and Technology, University of Debrecen, Debrecen

\section{Summary}

A combination of land cover data and WRB diagnostic traits was used to form four soil groups based on the extent of anthropogenic influence: 1. areas with no soil, 2. areas with anthropogenic soils, 3. natural soils with evidence of human transformation, 4. soils in a natural condition. All the land cover classes could be unequivocally assigned to one of these groups. This method was then applied to evaluate the naturalness of the soil cover in Hungary. No soils meeting the definition of soil according to FAO guidelines were found on $2 \%$ of the land surface, anthropogenic soils (Anthrosol or Technosol) were characteristic of 6\%, natural soils on which the level of anthropogenic activity reached the WRB diagnostic limit values made up $66 \%$ of the land surface, and only $26 \%$ of the soils were in a natural or near-natural condition. In terms of diagnostic soil types, the chernozem, meadow and alluvial soils exhibited the greatest extent of anthropogenic influence, while most of the soils in a natural condition were skeletal and lithomorphic soils. There were also considerable territorial differences: the highest rate of anthropogenic transformation was found in the Hajdúság and KörösMaros Köze regions, while the highest proportion of natural soils was recorded on hilly areas in the Northern Mountains.

The method developed for evaluating the naturalness of the soil can only be used as a rough estimate, but it nevertheless gives a good idea of the extent to which Hungarian soils have been exposed to anthropogenic effects, and of the importance 
of human activity, which is considered to be the sixth soil-forming factor, but which has been less well studied than the other five factors.

Keywords: anthropogenic influences, soil naturalness, land cover, WRB diagnostics

\section{Tables and figures}

Table 1. Diagnostic elements expressing anthropogenic soil features in the WRB soil classification system (IUSS Working Group WRB, 2015)

Table 2. Grouping of CORINE (CLC100) land cover classes according to the level of anthropogenic soil transformation and the WRB diagnostic traits characteristic of each class

Figure 1. Expected grade of anthropogenic soil transformation in Hungary based on CLC100 (2012) land cover classes

Figure 2. Distribution of anthropogenic transformation levels over diagnostic soil types, based on the area of each type in Hungary

Figure 3. Level of anthropogenic soil transformation within the mesoregions of Hungary 